\title{
1. Chaos: the unspeakable other to origins and organizing
}

\section{Gibson Burrell}

\section{INTRODUCTION}

In answering the question of what has been marginalized or unrecognized within Organization Theory, it is difficult to know where to begin. So much has been kept behind locked doors, or swept under the carpet, or blindly ignored by those charged with contributing to the discipline. The first thing to note, of course, is precisely that it is a 'discipline', which entails in its very nature the foregrounding of certain issues and the backgrounding of others. More 'mature' debates about the 'Pfferdigm' (Van Maanan 1995) are repeated in what turn out to be newer repetitions of the same arguments about positioning the discipline in relation to economics. We are told to become isomorphic, not only with economics and mimic its internal arrangements and its command and control systems, but internally too, so that inside Organization Theory, practitioners will be able to put on a united front when faced with interdisciplinary competition.

In the face of such strictures, Organization Theory would have to abandon many of its quirky features. Davis (2015) suggests that our discipline is not a cathedral of uniformity and strength built on a shared belief system but is a 'mystery house' wherein the ghosts of the past still haunt us. We are told to abandon the mystery house with its unplanned corridors that twist in a 'shambolic' way, full of the indistinct murmurings of the dead, and replace it with a single edifice devoted to monotheism and to Davis's ex cathedra pronouncements which will be, without question, for all of our good.

Mike Reed and myself (2017) have begun to ask what would be the consequences of this move from mystery house to cathedral, but there is not space to undertake that task here. Suffice it to say that the ghosts of the mystery house definitely need to be remembered by our discipline, and blind, darkly lit corridors are sometimes just as interesting as 
straightforward passages leading into the daylight. In this chapter I wish to explore a dark, blind cul-de-sac of Organization Theory that rarely sees the light of dawn ... Chaos. And I want to examine Chaos in relation to organization by leading the reader through the twists and turns of a critical cul-de-sac.

\section{ABANDON HOPE ALL WHO ENTER HERE}

'Organization Theory' is equally bad at geography and history. Space and time often leave us cold. Proponents of the discipline often write out non-Western concerns and ideas, and are equally partisan in their portrayal of history. This may be due to the overwhelming reliance on a philosophy of pragmatism (Joas 1993) rooted in the USA for over a hundred years, but it is also surely related to a belief in 'Occidentalism' and the natural superiority in Western management techniques and Western natural and social sciences upon which the former depends. Where ideas from the 'East' or the 'South' (labels which fix one's own location as the viewing point from which all must be seen) appear to bring economic advantage or offer new forms of labour control, they may be readied for import through bespoke modification and aestheticization for Western taste. But by far and away more important is the use of Western ideas by Westerners for Westerners. Boundary maintenance is encouraged and enforced by keepers of the keys to the homeland which must be defended at all costs. And of course, this action is clearly a problematic move of exclusionary import. Yet, in a moment of confession, in this chapter I wish to do something similar - although at the edges of history rather than geography.

I wish in this chapter to patrol the edge of 'Chaos' and the edge of 'organization', allowing only certain credentialed elements to enter or leave. This liminal world is, and has been in recent years, the province of management consultants seeking to thrive there, so the patrolling of this historical time and space is crucial in preventing a robbing out of what is central to our treasured disciplinary tradition by those who have no real interest in it. Whereas these consultants operate under the illusion of a totalizing management controlling an overarching domain, my attention will be on the complex relationship between organization and Chaos and to assess whether and how they might overlap or be seen as totally separable.

The normal and normalized move at this point would be to start with 'organization' as our core concept and move onwards and outwards from there. Not here. I wish to start with Chaos as the defining term of 
'Organization Theory'. It is our sine qua non, yet we tend always and everywhere to ignore it. It is the most important term we have because it scares us - or it should scare us - immensely. And every disciplinary nexus needs to be scared shitless from time to time.

\section{THE ORIGINS OF ORGANIZATION THEORY IN RELIGION}

Of the many areas of human knowledge that Organization Studies has tended to neglect, one is religion. Therein, there is an emphasis on mystery, the ineffable and the inexplicable which fit somewhat uneasily into social science. But it is into religion - particularly theology - that we must now step briefly in order to understand the centrality of Chaos to human thought - and not just in the West. Chaos has as its Other - that by which it knows itself - the notion of creation or, somewhat differently and confusingly, the notion of cosmos.

David Christian (2004: 17-18) asks a big question about the act of creation,

How did everything begin? This is the first question faced by any creation myth and ... answering it remains tricky ... Each beginning seems to presuppose an earlier beginning ... Instead of meeting a single starting point, we encounter an infinity of them, each of which poses the same problem ... There are no entirely satisfactory solutions to this dilemma. What we have to find is not a solution but some way of dealing with the mystery ... And we have to do so using words.

The use of words, both written and spoken, takes us into mythology and the subject matter of a 'perennial philosophy' (Armstrong 2005: 4). There are probably cosmogenic myths in all religions through which the order of the world (cosmos) is explained but these may be seen to be of two major types. The first is 'named' transcendental and is found in Judaism, Christianity and Islam, where an omnipotent god exists totally independent of its earthly creativity. On the other hand, there are religions in which it is believed that all creation needs constant attention, usually in the form of rituals in order for the gods to maintain their vigour and vitality in sustaining order and stability in the human world. These are termed cosmogenic religions and are associated with early civilizations and prehistoric belief systems. In this view, 'ritual makes creation over again' (Eliade 1993: 346). Indeed, the whole order of the universe depends upon ritual being carried out, regularly and in the here and now. In this major sense lies the difference in mythology between cosmogenic 
and transcendental religions and which behoves us, residing in the West, to think more carefully about the ways in which Chaos and creation are conceived in the rest of humanity (Insoll 2011).

However, the complexity of this originary scene is such that multiple layers lie enfolded upon multiple layers of interpretation. As Armstrong (2005: 11) says, 'There is never a single, orthodox version of a myth.' Instead of seeking to differentiate theologies by the importance of ritual, some authors, such as Mircea Eliade (1960, 1994), developed a 'cosmogony' in the 1950s, reflecting a kind of structural universalism (Eliade 1959; Insoll 2011). It is concerned with the origin and the creation of gods and the cosmos, and looks at the founding myths of the ordered universe in particular. Eliade claims that the only function of myths everywhere is to create a sacred cosmos from the primordial chaos and that all rituals are reflective of the cosmogenic myth. Organization Theory, in this view, would have its origins in the ancient myths of a sacred cosmos.

In an equally universalizing move, the concept of the Axial Age, developed by Jaspers (1953), looks to the development of several key religions in Eurasia in the same time period, namely 800-600 BCE. Thus, Buddha (c. 563-483 BCE) and Confucius (c. 551-479 BCE) were both contemporaries of the Pre-Socratic philosophers from around the Ionian Sea, whilst at the same time in the Levant, monotheism was being developed (Dobson 2005). This may be assumed to be the period in which religion 'begins'. Individual consciousness is elevated to a role of distinct significance, operating in parallel alongside the previously predominant mode of the collective worshipping of a commonly perceived deity in uniform ways. Myths are interiorized by individuals in this age, entailing that: 'This radically different religious experience meant that mythology could no longer easily speak about the divine in the old anthropomorphic way' (Armstrong 2005: 87).

Creation and Chaos, and the mythologies acting in their name, then, gradually become unspoken about as the Axial Age develops. During the later 'Great Western Transformation', of course, it is not 'mythos' which governs human thought but 'logos', and it is here where Organization Theory starts to become more comfortable about its origins. Religion bows to Science. Myth has given way to Reason. Chaos stands aside in favour of Organization.

But let me resist the temptation to yield ground to familiar totems of rational organization and take us one more time, via the eternal return, to the conceptualization of the Other to organization - that is to our discipline's mortal enemy, Chaos. 


\section{IN THE BEGINNING WAS CHAOS - PERHAPS}

Perhaps, the first possible history of the concept of organization should be one based on 'magic realism', in which the inexplicable and the everyday, reason and fairy tale, are combined (Armstrong 2005: 147). Thus, we deal perforce with the formless void and its relation to myths of creative organizing. The Tao Te Ching helpfully says that 'The unnameable is the beginning of heaven and earth.' But almost immediately the human species seeks to label this prelapsian non-world in order to begin to know it. In several civilizations the equivalent of 'Chaos' and 'disorganization' are to be found, but by this act of nomination, humanity steals from the unspoken, unthinkable abyss of nothingness, its very nature. If social systems believe that 'chaos' was truly unnameable then humanity has spent a considerable amount of its time in seeking to label it through mythological contrivances. To form the formless, as it were, seems to be a human preoccupation (Armstrong 2005; Burrell 2013).

In seeking to understand this act of naming what is the truly eternal absence, we must be wary of comparing the relative precision of Romance languages and their words with the Chinese ideographs. By being context-dependent, ideographs paradoxically allow for a much wider range of meaning for terms and their interpretation. In China, moreover, cosmogenesis was eschewed (although, of course, there were rites and ceremonies and heroes that had to be followed if disorder was to be held at bay). So there are cultural differences here of which to be aware but, in the West, there is a widespread notion that 'In the beginning was the word.' Chaos is subdued by naming it. Fear abates and comfort is taken. The nomination of 'Chaos' is a comforting approach to the labelling of a world inhabited by humans facing their regular search for dangerous game or enduring fear of unpredictable rains. Myths reflect a perpetual struggle to the death. But we shall return later to the uncomfortable question of what if Chaos were to remain nameless and unknowable.

In Indian, Chinese and Biblical approaches to the myth of creation, we begin to see what the formless void was meant to contain, once creation had begun to work its magic. And these myths are by no means the same in answering the question, 'Before creation, what was there?' Schematically, Insoll (2011: 2), following the entry on 'Chaos' in Encyclopaedia Britannica, produces 'several different types of cosmogenic myths classified according to their symbolic structure'. These are (1) creation from nothing; (2) creation from chaos; (3) creation from a cosmic egg; (4) creation from world parents; (5) creation through a process of emergence 
and (6) creation through the agency of an earth diver. These are not necessarily mutually exclusive but may appear in parallel. The complexity that humanity impresses upon Chaos continues thereafter.

In forming the formless, there are four Latin versions of this process we need to remember. These are creatio ex nihilo which means creation from nothing; creation ex materia meaning creation out of pre-existing matter; creatio ex deo suggesting the role of gods in creation and creatio continua which implies that matter and form are constantly being renewed as an ongoing process. Even today, these Latin differentiations continue to frame modern conceptualizations of a world seeking to organize. Castoriadis (1993), for example, is very keen to demonstrate that Jewish and Greek notions of chaos differ by virtue of the fact that, in the Old Testament, God fills the void whilst, for the ancient Greeks, there was nothing in the void at all. The consequence of this differentiation is that if humanity has indeed created the cosmos out of nothing, then in our brief time on Earth we may model the world as we will. It has not been laid out for us in a constraining, pre-existing order as it is under Judaeo-Christian mythology. Yet, pace Castoriadis, for Heraclitus, chaos provided the firm foundations of reality. And for Ovid, chaos contained a 'shapeless heap of discordant confused elements', yet these are the building blocks upon which humanity must construct and be constructed. To create, in this Romanized view, is to seize 'dark materials' from Chaos.

Thus, it must be noted that whilst we may well come across some bizarre bazaars wherein Eastern and Western ideas meet and interact, are repackaged and marketed, we cannot dwell long on the Silk Road. What we Occidentals call the structure-process debate, so-called 'male/female' principles of life and their role in the creation of organization, as well as the animalistic imagery behind most creation myths (snakes, bulls and cows predominate), all means we cannot hope to do these ideas justice. The hydraulic societies, identified by Karl Wittfogel (1957) and based in the large river basins of the world, produced heavens made up of animal deities which controlled human destiny. Japanese notions in Shintoism, yin and yang and the creation myths of Confucianism are also relevant here. So too, perhaps, is that crucial Arab invention related to nothingness - that of the zero (Rotman 1987) - or the Australian Aboriginal notions of 'dream time', or related ideas from Sub-Saharan Africa. All these conceptualizations of things and non-things, origins and endings, what will be and what might be, are part of the mystery house of Organization Theory, even if we wish to deny this. In all of this timespan - and span in space - it can be argued that the theorizing of the absence of form - the absence of organization - represents a widespread (even if 
not universal) concern of humanity. Does this mean that it is widely recognized that Chaos precedes all else? It does not (McGrath 2001: 296-305)!

Hence, the first thing to note is that Chaos is not. In other words, Chaos is often deemed not to be the first thing that ever existed. We discover, for example, in the Epic of Gilamesh (Sanders 1972), that this legendary King of Uruk in the Sumerian civilization from around 4000 BCE, was looking for what lay after death and the grave. The abyss here was not found before life began but after life had ended. Life came before the void and, for this civilization, Chaos was at the end of the World and not at its beginning.

Two thousand years later, the epic Babylonian creation myth of Enuma Elish (King 1999) tells of the daily battles between Marduk, the hero, and the sea monster Tiamat. In the German, this sort of narrative device is termed Chaoskampf (Tsumura 2005) - where a hero battles with a monster in order for humanity to live an orderly existence. Somewhat typically, one finds here a mixed myth of victory over disorder represented by a human, conquering over some thing that represents the crudely animalistic. Chaos is in the present, everyday, and it must be fought against heroically. One finds the repetition of this appealing variant in Hesiod's Theogony where again Chaos predates everything. Disorder of this magnitude is certainly not a telos towards which humanity is hurtling. Disorder existed in the past and has been conquered. In the Theogony, Hesiod has there, at the beginning, Chaos as the gaping void, the primordial abyss (Grant 1989: 103). We are not talking of the Grand Canyon here. Imagine, if you will, a space so vast that we travel down it in pitch blackness. There are no stars, there is no sense of our movement, there is no wind in our hair. We have no hair. No head, nor eyes, nor sense of self. No thought. There is no-one. No-thing. All is void and empty. There is absolutely nothing. It takes an eternity imperfectly measured by a single butterfly's erosion of a steel ball the size of the earth, landing for a fraction of a second every hundred years until the ball is eaten up by this lightest of frictions. And yet, our descent after all this time has yet to reach the topmost rim of the abyss. Yes, Chaos is a big idea.

There are important differences, then, in this concept of Chaos, because humanity in different times and in different places has engaged in naming the unnameable in different ways. These disputations revolved around crucial issues of what we seek to explain. Is the explanandum of Organization Theory to be order, or is it matter? More extensively, which of the four Latin conceptualizations of creation from nothing, from 
material, from God(s) or ongoing creation forever, appeals to Organization Theory more than the others?

First, then, is Chaos necessarily associated with an heroic story of order arising out of disorder and triumphing over it? Here, in a version of Chaoskampf, out of chaos there arises the creation of order (Tsumura 2005). This is the version of chaos and its demise that Organization Theorists might prefer. The placing of Chaos before we came along, offering as our discipline does the appeal to good order and sound management, is perhaps a more appealing narrative. For in this way, the discipline self-presents as being nearly all about stability and good government.

Second, is Chaos a necessary element of a narrative about the creation of things, even if, post-creation, matter and matters are still (or increasingly) in a state of disorganization and of disorder? Here, what is important is not order and stability but matter! Good order is less important than material substance. Thus, in this second projection, it is materiality which is seen as arising from Chaos, and 'things' of substance enter the world, whether organized or not. Perhaps the authors of the Bible seek to butter its liturgical bread on both sides by seeking an explanation of the creation of matter and especially living matter on one hand, alongside the creation of orderliness on the other. Within Genesis, the text deals with matter and order in a laminated way. One is described then the other, each taking a turn for mention. What God made, and what God put into order, alternate. Whilst the Babylonian gods required a constant unending struggle to maintain order in the face of Chaos, the Jewish Yahwah made the complete material world in six days and could afford to take a day off at the end of it (Armstrong 2005: 100). McGrath (2001: 296-307) argues that creation is presented in this tradition both as the imposition of order on formless Chaos and as conflict with a series of chaotic forces represented by monsters. So, Genesis shows that Nature is not divine but can be monstrous and, since God designed monstrosities as well as the moon and the stars, none of these should be worshipped as they were in the ancient shamanistic religions.

However, we must not forget that the Sumerian version is perfectly possible in which Chaos comes at the End and not at the Beginning. For the Sumerians, the beginning of the World is both materially resplendent and organized, and is orderly from the outset, yet it tends towards collapse. It would be foolish of us, therefore, to think that Hesiod's Theogony is the source of all these ideas of how creation comes about and what happens to Chaos (Pender 2009). Weingart and Maasen (1997: 479-80) are aware that Hesiod's conception of Chaos as 'not-form' and as always in the realm of the 'un-' (e.g., unformed, unthought, unfilled, 
unordered) does not produce every variant of Chaos. So, they claim of 'Chaos' that: 'Aristotle deems it void space; the Stoics, the undefined. Augustine equates it with hell ... Paracelsus regards it as the primeval matter of creation, and mysticism deems it the metaphysical cause of all things.'

Throughout the medieval period, Chaos continues to be theorized. We can find Raimundus Lullus (1232-1315) identifying in his Liber Chaos that Chaos is the primal form of matter created by God. Paracelsus (1493-1541) writes similarly about Chaos as we have just seen. Heinrich Khunrath in 1597 wrote an alchemy text entitled 'Chaos' which was taken up by Martin Rutland in his text of 1612, Lexicon Alchemiae. Throughout this period, Chaos is being appropriated as a resource by alchemists as it enters the world of quasi-science. In the humanities, however, as the Modern Age gets under way, it is Milton's Paradise Lost (2003) wherein we find some description of Chaos. In Book 2 (lines 890-97), the following stanzas appear:

Before thir eyes in sudden view appear [890]

The secrets of the hoarie deep, a dark

Illimitable Ocean without bound,

Without dimension, where length, breadth, \& highth,

And time and place are lost; where eldest Night

And Chaos, Ancestors of Nature, hold [895]

Eternal Anarchie, amidst the noise

Of endless Warrs, and by confusion stand.

And in Book 5 (lines 577-8), we learn:

As yet this World was not, and Chaos Wilde

Reignd where these Heav'ns now rowl.

For Milton, then, Chaos, in league with Night, is a non-World, a deep and dark ocean of limitless dimensions, characterized by anarchy, confusion and endless wars. It is replaced, after a long struggle, by rule from Heaven. And it is this story of the defeat and replacement of Chaos which comes into the modern period. So, by the mid-nineteenth century, two well-worn views of Chaos held sway. One saw it as opposite to order; by another account it was the source of order! What one notices in reading this material of a theological bent is that for every articulation of a position, over time this position is upended and transmogrified.

In summarizing this current section, perhaps it would be fair to say that Chaos is a bit of a big term, worthy, in equal measures, of disputation and of respect. Yet, Grant (1989: 109) argues that there are no cults of 
Chaos, nor 'have they a place in anthropomorphic mythology since it is difficult to imagine such lofty concepts'. Rhetorically he has placed Chaos above our heads rather than below our feet, but he suggests that Chaos is very rarely a starting point for analysis. That should not stop us in Organization Theory seeking to argue for the cult of Chaos! Indeed, I shall attempt to do so - in the briefest way - at the end of this chapter.

Let us accept for the moment that the Sumerians might have been right in assuming we humans are moving in the direction of the formless void, rather than away from it. Perhaps it would be helpful if we were to do a 'Martin Amis' (1991) in seeking to understand the reversal of time discussed in Time's Arrow. If we imagine the reversal of time, driven perhaps by a contracting universe, the end of organization rather than its beginning is the way to best conceptualize Chaos. In this thought experiment for Organization Theorists of the Chaoskampf persuasion, would 'organization' be more or less difficult in these circumstances and what would it mean for our discipline? Would managers be given even higher approval than they are in modern common cultural forms as they fight off the pressures of fragmentation just as Marduk does every night in slaying the beast? But what if the establishment of good order always, everywhere, creates its Other - the slide into Chaos. Perhaps managers like Marduk bring upon our heads, as well as their own, the Chaos they claim to constantly subdue (Fleming 2015). Yet, this musing is based on simple dialectics, so perhaps we should seek to escape from dualities. Unfortunately, we come at this point to 'Chaology' and Chaos Theory.

\section{CHAOLOGY}

Today, Chaos either means mild confusion and disarray in bureaucratic formalization as in Grey's (2012) study of Bletchley Park, or 'chaos' denotes a set of ideas which allude to the behaviour of complex, dynamically deterministic and non-linear systems. These ideas may compete with notions of chaos discussed above, or they may overlap and even complement them. In my view, the competition between today's chaologists and the old antediluvian notion of the creation myths is much more noticeable than any mutuality between them.

Weingart and Maasen (1997) see Chaos as a metaphor which allows myth, religion and science to reunite once more and it therefore became very popular for a period at the fin de siècle. Ian Stewart, a leading proponent of chaology, says apparently in agreement that: 
chaos has become a metaphor, but far too often the wrong metaphor. Not only is the metaphor being extended into areas where there is no reason to expect a dynamical system, but the very implications of the metaphor are being misrepresented. Chaos is used as an excuse for the absence of order or control rather than a technique for establishing the existence of hidden order, or a method of controlling a system that at first sight seems uncontrollable. (Cited in Sardar and Abrams 1999: 169)

From this quote one can see that 'Chaos' has changed its basic meaning considerably at the hands of the mathematicians and physicists. Although he did not use the term himself, Edward Lorenz, a Massachusetts Institute of Technology meteorologist, is seen as a founder of chaos theory in that he noted the slightest change in inputs to certain computer programs generated huge changes in outcomes. He later developed the 'flapping butterfly wings' label to describe this unexpected result but only when the term 'chaos theory' was attached to his work did Lorenz's system ideas take off.

The Social Science Citation Index shows an increase in articles with 'chaos' in the title from 23 in 1974 to 1008 in 1996. Twenty years later this rate of increase has tailed off dramatically. The Science Citation Index shows a similar rate of increase but at a level nine times higher. The targeting of Chaos, as we have seen, may be as old as the human spirit to impose form but, in 1960, Stafford Beer gave voice to this desire in his pronouncement that, 'Systems is one of the names for order, the antonym of chaos' (Beer 1960: 260). This forewarned of a deluge of material that sought to put Chaos to the sword by obliterating its meaning. Weingart and Maasen (1997: 465) say that within Western traditions, chaos was associated with: 'the unformed, the unthought, the unfilled, the unordered. This however is not to be understood as the opposite of order: at this stage chaos does not have any relationship to order at all.' But along come the chaologists, such as Ian Stewart (1989: 5), who proclaim that chaos is 'a technique for establishing the existence of hidden order or a method of controlling a system'. Thus, we are robbed of one of Organization Theory's most important notions: Chaos, that is conceivable, forever and always, as the absence of organization. Chaos and 'chaos theory' becomes the province of chaologists like Stewart who study 'unstable aperiodic behaviour' via 'dynamic systems theory'. It comes to be about messiness, surprises and noise. The philosopher Keith Ansell-Pearson (1997: 179) makes the very germane point here that for the chaologists 'all negativity only exists to confirm the immense self-recuperative powers of Reason'. In other words, if chaos exists as such a negative concept for humans to deal with, it needs to be tamed in order to show Reason will always prevail. Stewart acts as 
a member of the 'discursive police force' to remove one meaning from the literary and scientific world to replace it with another but using the same 'word'. Nigel Thrift (1999: 35), the bringer of chaos to his own institution, said 'complexity theory is one of the first fully mediatized scientific theories', but somewhat more critically, Weingart and Maasen (1997) say that 'this new scientific world view is honored with the wisdom of ancients'. Even more pointed are Best and Kellner (1999: 157) who declare that chaology and complexity theory represent 'new age metaphysics and neocapitalist apologetics'. The concept of Chaos then has grown from the unknowable to the controllable.

Here we come to the work of Haridimos Tsoukas (1998). In an uncharacteristic elision, Tsoukas appears to equate chaos and disorganization. As usual, the footnotes prove to be the most illuminating window into the author's thinking. Quoting favourably from Castoriadis (1987: 341) Tsoukas says disorganization 'is a concept that strictly speaking makes no sense' for 'all coherent discourse and all action would be impossible' (Tsoukas 1998: 309). Moreover, in the main body of the text, Tsoukas (p. 292) claims that 'we, as human beings, have no choice but to organize our world and our actions in it. The interesting questions are how we do it; what we do it for.' Notice here the rhetorical appeal to 'we' humans, presented as sentient beings whose language is central to disorganization.

Two problems present themselves in Tsoukas's article. The first concerns an apparent anthropocentrism, and the second is to do with the nominalist ontology on show. These are interrelated. For Chaos is brought into the world by we humans naming it. This unthinking embrace of humanism is often the start of debates in our area but it is only an assumption that humanity is the real force in the world for good or evil, and that plants, animals, rocks and trees play no part in what is important to the world (Curry 2011). Relatedly, both Tsoukas and Castoriadis (Adams 2005) rely upon typical nominalist assumptions that we humans create the world of trees and rocks and the Other by naming them, and that perhaps there is nothing outside of the text.

Might there not be disorganization in the 'real' world which we puny humans attempt to stave off, by fondly imagining that there is order in the known world? Umberto Eco (1979: 10) argued this position when he said, 'the only thing which makes the world terrible is our doomed attempts to treat it as if there was some underlying order to it'. Thus, unlike Tsoukas, I would wish to hang on to the notions that Chaos exists as disorganization but outside of our linguistic attempts to comprehend it. There must be room for the Other to 'organization', even in Organization Theory. Without this possibility we are doomed to a form of Orwellian 
newspeak. Just as Orwell (1949) showed that if good's opposite is ungood and not evil, then evil is removed from the world by taking its name from the vocabulary of expression, so in an equivalent way, the discipline is robbed of the immense significance of Chaos.

My desire is for disorganization to exist as a possibility, even though in mentioning it, and in bringing it into existence by this act, I strangle it at birth. For Tsoukas and the physicists and mathematicians upon whom he appears to rely, there is an intentional move to strangle Chaos anyway. Chaoskampf means the strangling of the beast is seen widely as the triumph of the will in its most rational form. Chaos in their grasping hands comes to mean unpredictability, surprises, novelty, non-linearity, disorder, messiness and noise. Here, then, chaology studies 'the behavior of a system which is governed by deterministic laws but is so unpredictable as to appear random, owing to its extreme sensitivity to initial conditions' (Stewart 1989: 10). The bottomless abyss has been eradicated by managerial fiat (Fleming 2015).

Where does this leave the happy conception of 'nothingness' - the nihilistic bottomless pit? For Tsoukas, it is clear that nothingness needs to be filled with both matter and order because the implication of the classical Greek insight of chaos as the gaping void, the abyss, the apeiron from which cosmos-form arises' (1998: 305, italics in original) implies Chaos has a role in bringing forth chaosmos. As in the Rig Veda (O'Flaherty 1981), this is not creatio ex nihilo but an emergence from a void in Chaos that is pregnant with the cosmos. One finds Castoriadis (1987) seeking a function for the void in that what chaos does, we are told, is to provide for the creation of new forms. From form comes order, in that well-known trope of creation emanating from Chaos. And so we are presented with both elements in the form of Chaosmos which gives us both creation and the void which gave birth to it. Chaosmos makes life patterned yet indeterminate. Chaosmos gives the human mind a role in the infinite. But this last point is its weakness. It privileges epistemology over ontology; the (Greek) human mind over the raw materiality of the universe(s). It rank orders the microcosm above the macrocosm. As Terry Pratchett (1983) would have had it, perhaps, it privileges the observers in their brass bathospheres over what actually lies under the rim of Discworld. Put crudely, in the hands of Tsoukas and Castoriadis, Chaos becomes a product of those humans who have invented themselves - and the term 'organization'.

Before we turn to 'organization' as a concept, Box 1.1 is offered as a hierarchy of positioning around Chaos, with the most chaotic-like conditions pertaining to the bottom-most part of this schema. After we have discussed the concept of 'organization' in detail we will then be in a 
position to add to Box 1.1 the ascending order of hierarchy for the term 'organization'.

\section{BOX 1.1 THE DESCENT OF CHAOS OUT OF CHAOLOGY}

Predictable regularities in large data sets

Unstable aperiodic behaviour

Matter is organized randomly

Matter is 'disorganized'

No matter

Nothing

The unfathomable abyss

The unnameable

The unthinkable

\section{THE CONCEPT OF ORGANIZATION}

Raymond Williams in Keywords describes the origins of the term 'organization' thus:

It is from the sense of organ as instrument or agency that organize and organization in their modern sense eventually developed, mainly from the late 18th century and early 19th century ... Organic followed a different course and indeed by the 19th century could be used in contrast with organized. (Williams 1983: 227, original emphases)

According to Williams (1983: 227), organ first appeared in English from the thirteenth century to signal a musical instrument; something akin to the modern organ appears in the fourteenth century. Its immediate forerunner was the old French word, organe, derived from the Latin organum, whose root word was opyvov in Ancient Greek. Organon could mean an instrument or an engine or a tool. It could also denote any human or non-human being's form as an instrument of its being, and could mean bodily organs conceptualized as instruments of the senses (eyes as instruments for seeing and so on), or surgical instruments or machines of war. In Latin usage, the focus came to be upon the last of these as organum came to refer to engines of war. In late medieval times, the meaning came back to concentrate upon church organs as instruments of praise to God. Cummings and Thanem (1998: 6) show that organons comes to the fore in the English tradition of the word from the sixteenth century. Harking back to a Greek strand of use, to organize means to 
endow with organs, but Cummings and Thanem (1998) maintain that a reference to 'to organize' from 1413 is the last before it reappears around 1870 in the English language. It dries up, perhaps, because it is replaced with a similarly derived word - the organism. What is abundantly clear in all of this is that, within and after the Renaissance, the complexities of meaning expanded so extraordinarily that it might serve our purposes to pause for breath and articulate some difficulties we must bear in mind before we race ahead of ourselves.

We must note at this point that the search for the origin of the term 'organization' is, like all originary quests, fraught with danger. We have Greek, Roman, Venetian, French, Anglo-American and Latin American sources for how and when the term is utilized. Cultures take different meanings from the term 'organization' and like many words it has become a 'portmanteau' signifier, allowing its user to carry many distinct meanings with them. The degree zero of a term - its root - is almost impossible to find given the origin, the original, the mother word, the moment of conception are located in complex phonemes and their linguistic transformations. The discovery of any document which is dated by readers so as to precede any other existing document does not necessarily signal primacy. It merely means this is the earliest version the contemporary world possesses. Accidents of papyrus manufacture or superior pieces of vellum may preserve one source rather than another but this does not indicate originality. Nor does discovery of a document ensure that our interpretation of its contents is accurate when translating terms from a specific spatio-temporal period into our linguistic codes. If 'the past is a foreign country; they do things differently there' (Hartley 1953: 9), it would be as well to remind ourselves of Vico's strictures (1999) on the limited use of history. Do not search for origins; and do not dare to believe we see the world as previous generations did. My purpose in using this assertion is to allow a political move which claims not to offer accuracy but rather to seek relevance for the present. To be allowed to say that for Organization Theory 'all is not system or organization' is a political statement in the current academic climate within our discipline.

And second, in speaking of politics, it may well be that there is a possible periodicity in the appearance and relative disappearance of the term 'organization' connected to political and economic events within the (Western) world. When branches of humanity come to believe that they cannot control or even understand the world through ratiocination, then thoughts turn to the problem of order. And when this happens, 'organization' has much to offer. As Karen Dale (2001) has shown, the links between rationality and organization are very clear after the Renaissance, 
when the 'anatomizing urge' comes to the fore. Within this form of thinking, organization means to endow with organs, whilst ratiocination comes to mean to allocate proportions or rations or ratios. 'Organized rationality' thus becomes the allocation of portions of meaning through the 'insight' of the human body allowed by the newly allowed practices of human anatomy. Chaos, happily outside this rational realm, is kept at bay by more and more intensive forms of social and psychological probing with scalpel and speculum, the culmination of which appears in Hegel's dictum 'what is rational is actual and what is actual is rational'.

Third, if we apportion the origins of the term 'organization' to the ancient Greeks, it places the focus on Western interpretations of meaning. Of course, this Occidentalism places very little worth on the Oriental perspectives, as Said (1989) so carefully showed. It has been argued in many places that the Alexandrian invasionary diaspora eastwards took Greek ideas to the Orient so that the Nyaya school of Indian philosophy looks very like Aristotelianism, for example. However, there are severe consequences arising from the assumption of an Athenian or even a Pan-Hellenisitic starting point. We neglect the Eastern notions of creation, order and system because they are seen as derivative of the West, when that may well not be the case (Insoll 2011).

At this point in our complex narrative, we come across the French Revolution and the notion of l'organization. This is the term used by Michel Foucault (1980) in The Order of Things and reflects a French tradition going back to Saint Simon. Foucault's translator for the Tavistock edition of The Order of Things translates l'organization as 'organization structure', but this is unlikely to give us the full subtlety of the original French meaning. In the French Revolution, the rise of rationalism at the foot of the guillotine puts doubt upon, and in, Christianity and indeed problematizes all religious proclivities. Anti-clericalism becomes rampant and the encyclopaedists seek to understand all knowledge that is useful to humanity - or Man, as they would have said. Diderot's tree of knowledge is the classic example of such a search for codification and rationality. L'organization becomes a term for understanding both biological and non-biological events, problems and 'systems'. Rationality implies that there are connections between elements that follow rules, not least of which is that they are structured in particular, predictable ways that are repeated cognately across the social, natural and material worlds. This became known as the principle of organicism and represents the triumph of biologism amongst the sciences. Organicism ruled as a French way of understanding the world for at least a century and was exported to the USA in the late nineteenth century where it took root. 
In the USA, a key figure in the adoption of organicism was L.J. Henderson who, borrowing Pareto's Italian rendition of the concept, was very successful in establishing its centrality in Harvard. As a biologist by training, Henderson saw organicism's dependence on biological notions as a natural progression for his interests and those of social science generally. He and the group around him proceeded to develop notions of the social system deeply rooted in the organic metaphor. Henderson's sponsorship of sociologists led to the development of the Pareto Circle at Harvard which consisted of Parsons, Merton, Barnard, Mayo and Whitehead, amongst others. This stellar line up of organization theorists was to become fully familiar with Pareto's concern for organicism. To explain this, we might suspect that their sociological interest in the organic metaphor comes out of the political advantages to such an elite grouping proffered by an emphasis on social well-being, wholeness and the need for integration. As Hughes (1958: 277) puts it, Paretoeans 'viewed political life from the standpoint of the rulers'. Outside the leafy confines of Harvard, the population of Boston and, of course, well beyond, were agitated by the slump of the 1929 crash and Pareto ('the Marx of the bourgeoisie') offered a social theory, not of revolution, but of organic togetherness.

We move south now to Chile and the remarkable rise of the concepts of self-organization and autopoiesis. Mingers (1995) is clear that these two concepts are very different and should not be conflated. For him, self-organization theorists such as those based at the Santa Fe Institute in New Mexico see organization as a structural form from which develops complexity. 'Organization' herein equates to the static, enduring and patterned form from which complexity arises. Theorists of autopoiesis, on the other hand, see organization and structure as very distinct. Using a classic structuration model, structure is seen as surface events whilst organization obtains at the level of deep structure. In other words, organization is to do with the foundational properties of the system as a whole. So why Chile?

Stafford Beer used to claim that he and the concept of cybernetics played a role in Salvador Allende's thinking when the latter was democratically elected to the position of president of Chile. Yet it is his fellow nationals, Varela (1981) and Maturana (1975), who are most closely associated with autopoiesis. Beer maintained in lectures that it was the geography of Chile and its spatial form, which resembled more of a stretched linearity than a centralized circularity (which is much more normal for the shape of a nation state), that made the social, economic and political 'organization' of this South American state very difficult. 
Allende was not the first Chilean leader to see the difficulty in controlling and developing such an unusually shaped territory, but he sought advice under his socialist regime to improve control, command and communication throughout the length of Chile. Space here played a key role in concerns of an organizational kind, a fact that, perhaps, has not been recognized enough.

Cybernetics is spoken of less today but the notion of self-organization is still to be found where information technology is being discussed. The algorithmic 'turn' in information technology has created forms of organizing that are meant to resemble autopoiesis where the system is responsive to change, and rapid adaptation follows. Maturana (1975) and Varela (1981) focused upon disappative structures which are presented as massive networks of very complex feedback loops that are able to create, reproduce and adapt themselves. These structures are meant to 'structurally couple themselves' to their environment and form extensive assemblages. This is what is meant by self-organization. And history is built into these structures as an ontological grounding. Yet self-organization comes from within the organism. Thus, Watson (1998: 103) takes Prigogine's brand of complexity theory (1980) and says, 'The, now well-known, scientific evidence shows that spontaneous emergence of ordered systems within torrential flows of matter and energy (without divine intervention) opens up immense possibilities.' Organization here arises spontaneously and without intervention, from a torrent of material flows. Like an early unicellular life form in early Earth's primeval soup, perhaps.

Less biologistic (but not entirely so) is 'the production of organization', which is a term developed by Bob Cooper and a number of Cooperians influenced by his work. Here there is a strong antiCartesianism with an emphasis on flow, process and becoming. This may be thought to be a form of neo-Bergsonism in which there is a concern for duration in structures and how this is to be explained; a view of a material flow from the external into the internal of the organism but also a problematization of boundaries between what is properly in and what is out. Self-organization again is the focus but with processes becoming seen as more important than structures. Robert Chia (1998) in In the Realm of Organization argues for an epistemology of process movement - process and becoming - all within a logic of otherness where the concern is for the 'lost void'. This refers to those absent presences in any texts, allowing authors to focus upon technologies of representation (especially writing) and how voids and volumes are produced. 'Organization' here comes to mean all that is said and all that is not said, which is quite a totalizing project. The Cooperians, on occasion, attempt to 
begin this project and speak of the production of organization everywhere and at all times. But within Zen it is said 'attempting to define it means you fall into that net of words wherein nothing can be said', which takes us back perhaps to chaos as unspeakable.

\section{THE CREATION MYTHS OF ORGANIZATION THEORY}

As was argued earlier, the seeking out of origins is dangerous. When starting out on a search for a family history, one is warned that there are things that will turn up that you might not want to know. Some bastard always comes along to spoil things. The development of our discipline is often presented as unilinear and cumulative wherein improvements are worked upon that add to the sum of human knowledge by taking debates in a different direction whilst still showing immense respect for those previous pioneers. But this leaves bastardy outside in the cold. What things exist in our genealogy, then, that we might not want to know?

Well, for one thing, Organization Theory is fully implicated in war, its preparation and conduct. Max Weber spent a lot of his time writing and agitating for a general staff that would make Germany proud at the time of World War I. In my own delving into the archives of F.W. Taylor, I came across a letter where Taylor was asked for his advice on what to do with decidedly second-rate ball bearings that were meant to be used for lubricating mechanisms in engineering tools. His recommendation to Gantt was to sell these below par products to the US Navy arsenals for use in filling shrapnel shells. His particular work at the Watertown Arsenal in Boston is of historical interest because of union resistance, but the key point is that Taylor and his associates were trying out many of their ideas on military products for use against enemies of the state. The Tennessee Valley Authority study of fame in our area (Selznick 1949) considered the process by which large weapon sites were placed in the Valley deliberately in order to consume huge amounts of hydro-electric power being produced by the damning of the river and its tributaries.

The training of disciplined forces from which Taylorism and management control of the labouring classes emerge, owes much for example to expansionary monarchs such as Louis XIV, William of Orange and Frederick of Prussia. The disciplining of the military body allowed the disciplining of the body politic. Organization produces standing armies which are drilled into submission. Historically, our discipline has been at the forefront of improving command and control systems for the armies of the West. In short, Organization Theory is fully implicated in the conduct of civil and international warfare. Yet why has this history been 
ignored and left to military historians? Is it that it is too difficult to think of our involvement in warfare when we like to think it is our involvement in welfare that defines us, perhaps?

There is no room here to discuss the other dirty secrets we possess in our role as Servants of Power (Baritz 1960) that are written out of the authorized biography of Organization Theory but they are in need of articulation, whatever the risk to the messenger. If this needs reiterating, I am in favour of social scientists taking dangerous risks, especially in an age when risk taking is frowned upon by our superiors. Let me ask the question, more easily allowed when one is at the end of a career, 'What is most risky to Organization Theory?' Is it our code of ethics and the lack of them? Or might it be our aesthetics that precludes, at the outset, looking at below the rim of the disciplinary bowl? In asking ourselves what might undermine our disciplinary basis entirely, my nomination would be the notion of 'Chaos'.

\section{THE CULT OF CHAOS}

The last sentence uses future tense, for there is not space here to even sketch out, never mind develop, a cult of Chaos. Any putative cult of Chaos could claim to be marginalized and unrecognized in Organization Theory because to my knowledge it does not exist. If it did, it would not meet in the Mystery House but in a Tower of Babel. Yet, even within the ruins of humanity's efforts to know everything, the previous warning from Keith Ansell-Pearson (1997: 179) that 'all negativity only exists to confirm the immense self-recuperative powers of Reason' needs to be heeded. My attempt to describe the basic outlines of such a cult would immediately confront the problem of seeking to use Reason to enfold, capture and ensnare 'Chaos' for our purposes. Thus, it is easier to say what this cultic mission would rather seek to avoid than what it should promulgate. For it is in the nature of cults to secure their own identity by seeking out those who oppose them and whom they oppose.

So, who and what would the Chaos cultists label as problematic? Well first there are those like Lash and Urry (1987) who, as the title of their book suggests, speak of the End of Organized Capitalism as a form of rupturism. Originally this rather good book was to be entitled Disorganized Capitalism, but the authors became aware that what was actually at stake was the reorganization of capital after the mid-1980s rather than a discrete break to, and end of, what had gone before. Organization insinuates itself everywhere even as one form changes in ways that are hard to perceive. Rupturism is not an orientation that a cultist of Chaos 
would look to as a place to spend time, for notions of endings and reorganizations of this kind are well within the mainstream of Organization Theory. Attention would not be focused upon discrete changes for these are not Chaotic in the sense intended here.

Second in the firing line would be those like Grey (2012), who treats 'chaos' simply as a lack of formal organization, whilst the informal organization appears to function quite well. Shenhav (1995) shows that the typical solution to the presumed 'chaos' witnessed by owners in machine shops around World War I was thought to be 'extra clerks' - in other words more bureaucrats. Bletchley Park was administered by bureaucracy and informality in equal measure. But given it was under military control this dual-control system is by no means unusual. There is much evidence that armed forces are typified by highly formalistic and bureaucratic structures in peacetime, and even in wartime behind the front lines, but once combat breaks out, informality and bureaucratic transgression are favoured by all concerned as expressions of 'initiative' in the face of enemy contact. The surprise that Grey evinces would not have been so great, perhaps, if any comparison had been made of Bletchley with military units in direct contact with the enemy. This is not Chaos that the cult of Chaos would identify in any way. It is bureaucratically sanctioned spontaneity in the face of war.

Third, then, coming to war and its organization (Bloomfield et al. 2017), surely, the reader might ask, do we organization theorists not see the full 'Chaos' of the cultists' gaze in the destruction of people and places in a wartime situation? Take for example Hiroshima in the first hours after the dropping of an atomic bomb in August 1945. At ground zero was there any meaningful 'organization' to speak of? All was, as Ovid put it, 'a shapeless heap of discordant confused elements'. Here, then, we see on the planet in the twentieth century something akin to Chaos as might be imagined. It allowed Oppenheimer (so-called Father of the Bomb) to compare it to images found in Indian philosophy of widespread destruction at the end of the world. But within days, streets had been cleared of rubble and the grid system of Hiroshima reappeared and the one or two concrete buildings that had withstood the blast were reoccupied. Chaos came briefly and was put to the test by human ingenuity and resilience, to say nothing of Nature, which reinsinuated itself into the rocks and rubble as greenery. Even here, then, the cult of Chaos has little to study in the empirical realm. Yet, despite this, we must retain the notion of 'Chaos' as free, not only from the chaologists but from those who wish to occupy it with societal ruptures, everyday poor organization and military destruction. 


\section{CONCLUSIONS: MYTH, MUSIC AND METALLURGY}

Organization Theory owes its origins to three things. Organization comes in the form of myths where the world is made less terrible by stories of its cohesion and comprehensibility. Sitting around a fire as the Ice Age retreats, but the cold winds still blow, pushes the tellers of tales to consider air, fire, earth and water. And these stories involve so many totemic animals because of the danger they represent to human life, yet also the resources they offer to sustain it. Organization arises here. Music and its making also offer the opportunity to 'organize', whether it is one's tribal members or rhythms or making a noise to scare away the wild beasts of the night. Sound organization (Corbett 2003) indeed. And finally, organization comes from metallurgy (Diamond 1997) and the ways in which humanity strives to find stronger and sharper materials by which to incise the world with our marks.

But what of the future? Clegg et al. (2005: 11) remark, 'With regard to conventional analyses, organization is not understood in terms of flux, emotion and unpredictability. Instead, it is seen as a means of ordering, structuring and controlling the chaotic world outside.' In a seemingly chaotic world, it appears that human beings 'need to create a sense of order and make arrangements with each other, both to achieve security and to meet material needs' (Watson 1994: 222). But these may not be dualities in opposition. They may well be better conceived as a continuum, as revealed in Box 1.2, which is a summary synthesis of the discussion of the term 'organization' offered in this chapter. At one end of this continuum is to be found the most difficult concept in Organization Theory - the unthinkable. At the other end is a term that might lay claim to be the origin of organization and the first term to confront Chaos on a conceptual head-to-head basis - the organon. This is simultaneously the metal tool, the musical instrument and the plot device from which, in consort, Organization Theory arises.

In their comments above, Clegg et al. (2005) and Watson (1994) reflect two things with which one might agree. First, there is the notion that a certain 'will to form' and a desire to keep chaos at bay is central to human understandings within a world that appears 'seemingly chaotic'. Second, the sort of understanding that these authors offer is relatively missing from 'conventional analyses' and that is problematic. But what is missing from this relative openness to 'flux' is a full and enthusiastic embracing of the notion of Chaos. 


\section{BOX 1.2 THE PRODUCTION OF ORGANIZATION AND ITS OTHER}

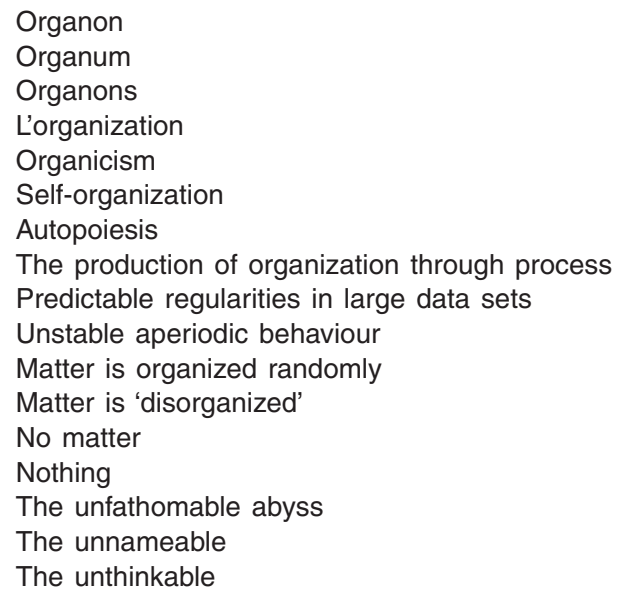

Chaos is the ghost at the table of Organization Theory, hidden behind the arras, out of sight and out of mind, unspoken and unrecognized for what it is. Chaos is the absent presence which makes organization possible. To continue to treat the idea of Chaos as recuperable as if it is merely a signifier of mild disorder, or rescuable as if it is merely the set of ideas mathematicians and physicists carry around with them when discussing dynamic systems is doubly unacceptable. Nor is Chaos merely a pool of ideas and matter, a reservoir replete with possibilities to be used for bringing forth organization, a residence of potential from which we were spewed up. Chaos needs to be brought out of the closet and opened up to allow us to look, with wonderment, into that terrifying maw which in time will devour us whole.

\section{REFERENCES}

Adams, Suzi (2005). Interpreting Creation: Castoriadis and the Birth of Autonomy, Thesis Eleven 83(1), 25-41.

Amis, Martin (1991). Time's Arrow, Jonathan Cape, London.

Ansell-Pearson, Keith (1997). Viroid Life, Routledge, London.

Armstrong, Karen (2005). A Short History of Myth, Canongate, Edinburgh.

Baritz, Loren (1960). Servants of Power, Wesleyan University Press, Middletown, CT. 
Beer, Stafford (1960). Cybernetics and Management, Journal of Symbolic Logic 25(3), 258-78.

Best, Steven and Kellner, Douglas (1999). Kevin Kelly's Complexity Theory, Organization and Environment 12(2), 141-62.

Bloomfield, Brian, Burrell, Gibson, Suchman, Lucy and Vurdubakis, Theo (2017). Licence to Kill: The Organization of Destruction, Organization 24(5).

Burrell, Gibson (2013). Styles of Organizing, Oxford University Press, Oxford.

Castoriadis, Cornelius (1987). The Imaginary Institution of Society (trans. Kathleen Blamey), Polity Press, London.

Castoriadis, Cornelius (1993). The Greek Polis and the Creation of Democracy. In Philosophy, Politics, Autonomy (trans. David Ames Curtis), pp. 81-123, Oxford University Press, London.

Chia, Robert (Ed.) (1998). In the Realm of Organization, Routledge, London.

Christian, David (2004). Maps of Time: An Introduction to Big History, University of California Press, Berkeley, CA.

Clegg, Stewart, Kornberger, Martin and Rhodes, Carl (2005). Learning, Thinking, Becoming, Organization 12(2), 147-67.

Corbett, Martin (2003). Sound Organization: A Brief History of Psycho-Sonic Management, Ephemera 3(4), 265-76.

Cummings, Stephen and Thanem, Torkild (1998). Let's Think about Organizations as if They Were Organisms, Warwick Business School working paper.

Curry, Patrick (2011). Ecological Ethics, Polity, Cambridge.

Dale, Karen (2001). Anatomising Embodiment and Organization Theory, Palgrave, Basingstoke.

Davis, Gerald (2015). Celebrating Organization Theory: The After-Party, Journal of Management Studies 52(2), 309-19.

Diamond, Jared (1997). Germs, Guns and Steel, Norton, New York.

Dobson, Geoffrey (2005). A Chaos of Delight, Equinox, London.

Eco, Umberto (1979). The Role of the Reader, University of Indiana Press, Bloomington, IN.

Eliade, Mircea (1959). The Sacred and the Profane, Harcourt Brace, New York.

Eliade, Mircea (1960). Myths, Dreams and Mysteries (trans. Philip Mairet), Tavistock, London.

Eliade, Mircea (1993). Myth and Reality, Waveland Press, New York.

Eliade, Mircea (1994). From Primitives to Zen: A Source Book of the History of Religions: Gods, Goddesses and Myths of Creation, Harper and Row, New York.

Fleming, Peter (2015). The Mythology of Work, Pluto Press, London.

Foucault, Michel (1980). The Order of Things, Tavistock, London.

Grant, David (1989). Hesiod's Theogony, Penguin, Harmondsworth.

Grey, Christopher (2012). Decoding Organization, Cambridge University Press, Cambridge.

Hartley, Leslie Poles (1953). The Go-Between, Penguin, Harmondsworth.

Hughes, H. Stuart (1958). Consciousness and Society, Harvester, Brighton.

Insoll, Timothy (2011). Cosmogony. In The Oxford Handbook of the Archaeology of Ritual and Religion, Oxford University Press, Oxford.

Jaspers, Karl (1953). The Origin and Goal of History, Yale University Press, New Haven, CT. 
Joas, Hans (1993). Pragmatism and Social Theory, University of Chicago Press, Chicago, IL.

King, Leonard William (Ed.) (1999). Enuma Elish, 3 volumes, Book Tree, San Diego, CA.

Lash, Scott and Urry, John (1987). The End of Organized Capitalism, Polity, Cambridge.

Maturana, Humberto (1975). The Organization of the Living, International Journal of Man-Machine Studies 7, 313-32.

McGrath, Alistair (2001). Christian Theology, Blackwell, Oxford.

Milton, J. (2003). The Complete Poems and Major Prose, Hackett Publishing, London.

Mingers, John (1995). Self Producing Systems, Plenum, New York.

O'Flaherty, Wendy Doniger (1981). The Rig Veda: An Anthology, Penguin, Harmondsworth.

Orwell, George (1949). Nineteen Eighty Four, Secker and Warburg, London.

Pender, Elizabeth (2009). Chaos Corrected: Hesiod in Plato's Creation Myth. In G. Boys-Stones and J. Haubold (Eds), Plato and Hesiod, University Press Scholarship, online.

Pratchett, Terry (1983). The Colour of Magic, Colin Smythe, London.

Prigogine, Ilya (1980). From Being to Becoming, Freeman, San Francisco, CA.

Reed, Mike and Burrell, Gibson (2017). The State of Organization Theory Today, Working Paper.

Rotman, Brian (1987). Signifying Nothing: The Semiotics of Zero, Macmillan, Basingstoke.

Said, Edward (1989). Orientalism, Penguin, Harmondsworth.

Sanders, Nancy (1972). The Epic of Gilamesh, Penguin, Harmondsworth.

Sardar, Ziauddin and Abrams, Iwona (1999). Chaos, Icon, Duxford.

Selznick, Philip (1949). TVA and the Grass Roots, University of California Press, Berkeley, CA.

Shenhav, Yehoud (1995). From Chaos to Systems, Administrative Science Quarterly 40, 557-85.

Stewart, Ian (1989). Does God Play Dice? Basil Blackwell, Oxford.

Thrift, Nigel (1999). The Place of Complexity, Theory, Culture and Society 16(3), 31-70.

Tsoukas, Haridimos (1998). Introduction: Chaos, Complexity and Organization Theory, Organization 5(3), 291-313.

Tsumura, David (2005). Creation and Destruction, Eisenbrauns, Warsaw, IN.

Van Maanan, John (1995). Fear and Loathing in Organization Studies, Organization Science 6(6), 687-92.

Varela, Fransisco (1981). Describing the Logic of the Living. In M. Zeleny (Ed.), Autopoiesis: A Theory of the Living Organization, Elsevier, New York.

Vico, GiamBattista (1999). New Science, Penguin, Harmondsworth.

Watson, Sean (1998). Chaos of the Body, Body and Society 4(3), 103-14.

Watson, Tony (1994). In Search of Management, Routledge, London.

Weingart, Peter and Maasen, Sabine (1997). The Order of Meaning: The Career of Chaos as a Concept, Configurations 5(3), 463-520.

Williams, Raymond (1983). Keywords, Fontana, London.

Wittfogel, Karl (1957). Oriental Despotism, Yale University Press, New Haven, CT. 